\title{
Identification of transcriptome induced in roots of maize seedlings at the late stage of waterlogging
}

\author{
Xiling Zou, Yuanyuan Jiang, Lei Liu, Zuxin Zhang, Yonglian Zheng*
}

\begin{abstract}
Background: Plants respond to low oxygen stress, particularly that caused by waterlogging, by altering transcription and translation. Previous studies have mostly focused on revealing the mechanism of the response at the early stage, and there is limited information about the transcriptional profile of genes in maize roots at the late stage of waterlogging. The genetic basis of waterlogging tolerance is largely unknown. In this study, the transcriptome at the late stage of waterlogging was assayed in root cells of the tolerant inbred line HZ32, using suppression subtractive hybridization (SSH). A forward SSH library using RNA populations from four time points (12 h, 16 h, $20 \mathrm{~h}$ and $24 \mathrm{~h}$ ) after waterlogging treatment was constructed to reveal up-regulated genes, and transcriptional and linkage data was integrated to identify candidate genes for waterlogging tolerance.

Results: Reverse Northern analysis of a set of 768 CDNA clones from the SSH library revealed a large number of genes were up-regulated by waterlogging. A total of 465 ESTs were assembled into 296 unigenes. Bioinformatic analysis revealed that the genes were involved in complex pathways, such as signal transduction, protein degradation, ion transport, carbon and amino acid metabolism, and transcriptional and translational regulation, and might play important roles at the late stage of the response to waterlogging. A significant number of unigenes were of unknown function. Approximately $67 \%$ of the unigenes could be aligned on the maize genome and 63 of them were co-located within reported QTLs.

Conclusion: The late response to waterlogging in maize roots involves a broad spectrum of genes, which are mainly associated with two response processes: defense at the early stage and adaption at the late stage. Signal transduction plays a key role in activating genes related to the tolerance mechanism for survival during prolonged waterlogging. The crosstalk between carbon and amino acid metabolism reveals that amino acid metabolism performs two main roles at the late stage: the regulation of cytoplasmic $\mathrm{pH}$ and energy supply through breakdown of the carbon skeleton.
\end{abstract}

\section{Background}

Waterlogging, caused by flooding, long periods of rain, and poor drainage, is a serious abiotic stress determining crop productivity worldwide [1]. Depletion of oxygen is a major feature of waterlogging, because the diffusion of oxygen in water is $10^{-4}$ times slower than that in air [2]. The imbalance between slow diffusion and rapid consumption of oxygen in plant roots drastically reduces the oxygen supply [3], which is vital to the survival of plant roots.

\footnotetext{
* Correspondence: zhyl@mail.hzau.edu.cn

National Key Laboratory of Crop Genetic Improvement, Huazhong Agricultural University, Wuhan, 430070, China
}

Plants respond to low oxygen through specific alterations of transcription and translation. The response was first studied in maize roots. Using two-dimensional electrophoresis, about 20 anaerobic proteins (ANPs) were shown to be induced during low oxygen treatment, while synthesis of aerobic proteins was drastically repressed [4]. Most of the ANPs were identified as enzymes involved in sugar phosphate metabolism, such as alcohol dehydrogenase, aldolase, enolase, glucose phosphate isomerase, glyceraldehyde-3-phosphate dehydrogenase, pyruvate decarboxylase and sucrose synthase [5,6]. Studies have subsequently identified alterations in the expressions of hundreds of genes in response to 
oxygen deficiency. These genes can be grouped into four subsets. Firstly, sensing and cell signaling, involving transient induction of mitochondria alternative oxidase (AOX) $[7,8]$ and activation of RopGAP4 (Rop GTPase activating protein4) $[9,10]$, which is related to the ROS species signaling pathway. The induction of calmodulin [11] and CAP (Calmodulin-Associated Peptide) is verified to have an important role in $\mathrm{Ca}^{2+}$ signaling $[12,13]$. In addition, various plant growth regulators involved in signaling cascades influencing cellular response are also induced under waterlogging condition [7,14-25]. Secondly, metabolic adjustment, reflected as a switch from aerobic respiration to anaerobic fermentation involving induction of ANPs acting in sugar phosphate metabolism, such as lactic and alcoholic fermentation. Thirdly, maintenance of $\mathrm{pH}$; in addition to the role of ANPs related to metabolic switch $[5,26,27]$, the activation of plant glutamate decarboxylases (GADs) interacting with calmodulin is related to $\mathrm{pH}$ regulation [7,28-30]. Lastly, other proteins, which include non-symbiotic hemoglobin, a protein that has been reported to be associated with many biological systems in hypoxia response [31-34]. Nitrogen metabolism [35] and cell wall loosening [36] were also identified to participate in the response to oxygen depletion.

Waterlogging can be conceptually divided into three time stages. The first stage $(0-4 \mathrm{~h})$ consists of the rapid induction of signal transduction components. This initial signal reception response in turn activates the second stage (4-24 h), a metabolic adaptation, including the induction of glycolytic and nitrogen metabolic pathways. In the third stage (24-48 h), which involves the formation of aerenchyma and the induction of xyloglucan endotransglycosylase, programmed cell death occurs in the roots [14].

Recently, Qiu et al. (2007) identified 34 QTLs for waterlogging tolerance in a set of $\mathrm{F}_{2: 3}$ families derived from HZ32 (tolerant inbred) $\times$ K12 (sensitive inbred) [37]. Several major QTLs for waterlogging tolerance were mapped on chromosomes 4 and 9. Secondary QTLs influencing tolerance were located on chromosomes $1,2,3,6,7$ and 10 .

Although many studies of the molecular mechanism of tolerance to waterlogging have been reported, there have been relatively few studies of transcriptomic and proteomic changes in maize [6,38-40] compared with rice [41], Arabidopsis [7,42,43], and other species [44]. In addition, these transcriptomic and proteomic studies mostly focused on the response to waterlogging at the early stage (0-8 h) in roots of maize seedlings. The late response (after $12 \mathrm{~h}$ ) of gene expression in root cells of maize is unknown. To gain an insight into gene expression changes in response to waterlogging at the late stage, a forward SSH library from four time points
(12 h, $16 \mathrm{~h}, 20 \mathrm{~h}$ and $24 \mathrm{~h}$ ) after waterlogging treatment was constructed using the tolerant inbred line HZ32. A total of 296 unigenes were identified as being induced by waterlogging and were clustered into 13 categories based on Gene Ontology analysis, suggesting the response involved a broad spectrum of genes and complex biological pathways. In addition, 63 unigenes were identified to be co-located with QTLs for waterlogging tolerance by an in silico mapping approach, and are thus important candidates for further breeding of waterlogging-tolerant crops.

\section{Methods}

\section{Plant material and growth conditions}

Seeds of HZ32 (waterlogging tolerant inbred line) were germinated for three days and the seedlings were individually transplanted into sand chambers. Plants were grown under $30^{\circ} \mathrm{C}: 22^{\circ} \mathrm{C}$ (light:dark, $16: 8 \mathrm{~h}$ ) until they initiated three leaves in total with two leaves expanded. Uniform seedlings were selected and divided into two groups. One group was cultured with a normal water supply as the control and the other was submerged in water with all leaves in air as the treatment.

\section{RNA isolation}

Roots treated for different time periods $(12 \mathrm{~h}, 16 \mathrm{~h}, 20 \mathrm{~h}$ and $24 \mathrm{~h}$ ) were immediately harvested, with eight seedlings representing a sample, and stored at $-70^{\circ} \mathrm{C}$. Roots of the controls were also harvested at the corresponding time point.

Total RNA was isolated using TRIzol (Invitrogen, USA) following the manufacture's recommendations. RNA quantity and quality were assessed by a Nanodrop spectrophotometer (Nanodrop Technologies, Montchanin, DE) and by agarose gel electrophoresis.

\section{Construction of the SSH library}

For the library, equal amounts $(250 \mu \mathrm{g})$ of total RNA from the four time points were pooled to form the mRNA $(2 \mu \mathrm{g})$ tester, while mRNA generated from the roots under normal conditions was used as the driver. SSH was performed with a PCR-select cDNA subtraction kit (Clontech, Japan) according to the manufacturer's instructions. Subtracted PCR amplified cDNAs were cloned into a pGEM-T vector (Promega, USA).

\section{Differential screening using reverse northern blotting}

To screen the true-positive clones, the inserts of all clones in the library were amplified by PCR with nested primers NP1 and NP2R. Approximately $5 \mu \mathrm{L}$ of PCR product was mixed with $5 \mu \mathrm{L}$ of $0.6 \mathrm{~N} \mathrm{NaOH}$ for denaturing, and $1.5 \mu \mathrm{L}$ of each sample was then arrayed onto two identical Hybond- $\mathrm{N}^{+}$nylon membranes (Amersham, UK). Membranes were neutralized in $0.5 \mathrm{M}$ Tris- $\mathrm{HCl}$ 
(pH 7.5) for $2 \mathrm{~min}$, and rinsed in distilled water for $30 \mathrm{~s}$. They were cross-linked by baking for $2 \mathrm{~h}$ at $80^{\circ} \mathrm{C}$ and then stored at $-20^{\circ} \mathrm{C}$ for later use.

Equal amounts $(5 \mu \mathrm{g})$ of total RNA from four time points were pooled, with treatment and control respectively, and reverse transcribed using M-MLV RTase cDNA Synthesis Kit (Takara, Japan) in presence of $\alpha$ $\left[{ }^{32} \mathrm{P}\right] \mathrm{dCTP}$ and used as probes. Membranes were hybridized at $65^{\circ} \mathrm{C}$ with radio-labeled probes in hybridization buffer (Toyobo, Japan) for $14 \mathrm{~h}$, then washed with $2 \times$ $\mathrm{SSC}, 0.5 \%(\mathrm{w} / \mathrm{v}) \mathrm{SDS}$ at $65^{\circ} \mathrm{C}$ for $10 \mathrm{~min}$, and $0.1 \times \mathrm{SSC}$, $0.1 \% \mathrm{SDS}$ at $25^{\circ} \mathrm{C}$ for $10 \mathrm{~min}$. Membranes were exposed to $\mathrm{X}$-ray film (Fuji photo film, Japan) at $-80^{\circ} \mathrm{C}$ for signal detection. Reverse Northern blotting was performed twice with a biological replication of the probes. The signals of the corresponding clones from both hybridizations were compared and the positive clones identified in both replications were selected. The randomly selected positive clones were sequenced (Invitrogen, USA).

\section{Sequence analysis}

Nucleotide sequences of ESTs > 100 bp were analyzed. Adaptor and vector sequences were removed with Phred-Phrap analysis software. All overlapping sequences were clustered into singleton contigs using DNAstar. A similarity search was performed by basic local alignment search tool (BLAST) at National Centre for Biotechnology Information (NCBI, NIH, USA) http://www.ncbi.nlm.nih.gov/BLAST/. In particular, blastn and blastx analysis were performed with an inclusion score $>50$. Functional classification of ESTs was carried out according to the functional categories of Gene Ontology (GO) http://www.geneontology.org.

\section{Real-time quantitative RT-PCR}

Three biological replications of total RNA were used for real-time quantitative RT-PCR. Total RNA was treated with RNase-free DNase. Reverse transcription of total RNA $(5 \mu \mathrm{g})$ was performed with an M-MLV RTase cDNA Synthesis Kit (Takara, Japan) following the manufacturer's instructions. Gene specific primers were designed using PRIMER3 software http://www.ncbi.nlm. nih.gov/tools/primer-blast/ (Table 1). For each gene amplified, $0.5 \mu \mathrm{l}$ of cDNA was used for the detection of amplified products.

Selected gene transcripts were quantified by real-time PCR using SYBRGreen PCR Master Mix (Takara, Japan) with three replications. The expression of actin was used as a control. PCR amplification conditions were as follows: $95^{\circ} \mathrm{C}$ for $2 \mathrm{~min}$, then 38 cycles of $95^{\circ} \mathrm{C}$ for $10 \mathrm{~s}$,
Table 1 Gene-specific primers for real time PCR

\begin{tabular}{|c|c|}
\hline Primer name & Primer \\
\hline \multirow[t]{2}{*}{ isovaleryl-CoA dehydrogenase } & CCACCACTACACTATCCCCTC \\
\hline & AGCGAACCAAACCACCGGCT \\
\hline \multirow[t]{2}{*}{ prolyl 4-hydroxylase } & TTCCGCGCCCGCGAAGAAAA \\
\hline & CAGGTGGGTGGTGTGGGGGA \\
\hline \multirow[t]{2}{*}{ glutamate synthase 1} & CGTGGTGGTTGTGGAGCGGA \\
\hline & AAGCCCTTGCTTGCTGGCCC \\
\hline \multirow[t]{2}{*}{ acetyl-coenzyme A carboxylase } & CGTGGTGGTTGTGGAGCGGA \\
\hline & AAGCCCTTGCTTGCTGGCCC \\
\hline \multirow[t]{2}{*}{ ethylene-responsive protein } & ATACGTCTCCGCCGCGTCCT \\
\hline & GCGTGAGCTCCCTCTGCTGC \\
\hline \multirow[t]{2}{*}{ alanine aminotransferase } & AAGGCCGAAGGAGCAATGTAT \\
\hline & GCAGCCTCGATTGCCTTCT \\
\hline \multirow[t]{2}{*}{ aspartate aminotransferase } & GGGTTGGATTTTGAGGGAAT \\
\hline & CCACTGTTCAGGAGTTGGGT \\
\hline \multirow[t]{2}{*}{ alcohol dehydrogenase } & GGGGATTCTGAAACCTGGAC \\
\hline & ACCCTTCTCAGAACAACCCC \\
\hline \multirow[t]{2}{*}{ sucrose synthase } & GGGGATTCTGAAACCTGGAC \\
\hline & ACCCTTCTCAGAACAACCCC \\
\hline \multirow[t]{2}{*}{ auxin response factor } & CACCAGGCACATGCAAAGAG \\
\hline & TाTTCCTGGGAATGCTGTTTCT \\
\hline \multirow[t]{2}{*}{ coproporphyrinogen III oxidase } & AAGGGGGAGGCCGGCAAGAA \\
\hline & TACCCGCGGCGAAGAATGGC \\
\hline \multirow[t]{2}{*}{ hypoxia induced protein } & GGTTGCTGGCTGCCTGGCTT \\
\hline & CCGTACGACGCTGGCTCACG \\
\hline \multirow[t]{2}{*}{ DNA-binding protein } & ACCGGGATTCCCTCCGCCAA \\
\hline & TCACCGCCAGCTTGGCATCG \\
\hline \multirow[t]{2}{*}{ ubiquitin-activating enzyme E1 } & ACCCGGGTGCACCATGGATCT \\
\hline & CATCGCCACTAGCCGCTCCC \\
\hline \multirow[t]{2}{*}{ putative MAPK } & TGCTGCAGCTGTGGACACCC \\
\hline & CCCGCAGTATGCGTGTGGCA \\
\hline \multirow[t]{2}{*}{ translation initiation factor elF- $2 B$} & CCCCTACCCCATCTCCCGGC \\
\hline & СCTCCACCTTCCGGCGCTTG \\
\hline \multirow{2}{*}{$\begin{array}{c}\text { protein phosphatase } 2 A \text { regulatory } \\
\text { subunit } A\end{array}$} & GCTCCTACCCTGCCCCGTCT \\
\hline & GGGGTCCGGATCGGGCTTCT \\
\hline \multirow[t]{2}{*}{ NADP-dependent malic enzyme } & AGCCAGTGGAGCCTTGGCCT \\
\hline & GGAGCAAGTGGAGGCTGCCG \\
\hline \multirow[t]{2}{*}{ Unigene285 } & TCGACAGCGGAGCGATCGAA \\
\hline & CCCCCGGGCAGCACATACCT \\
\hline \multirow[t]{2}{*}{ Unigene2 } & ACCAGGCTGGGGCAAGAGGA \\
\hline & ACCGTCACCACAGCGGGATCA \\
\hline \multirow[t]{2}{*}{ pyruvate kinase } & CAGGCTTCCGTCACAGGCAGT \\
\hline & CCAAGGCTCAAGAGATCACAGTTA \\
\hline \multirow[t]{2}{*}{ organic anion transporter } & CGAGCCGTGACCACCCAACA \\
\hline & GAAGATCTAGGCGGCGGCAGCA \\
\hline \multirow[t]{2}{*}{ actin } & AAGTACCCGATTGAGCATGG \\
\hline & GATGGAGTTGTACGTGGCCT \\
\hline
\end{tabular}


$60^{\circ} \mathrm{C}$ for $30 \mathrm{~s}$ and $72^{\circ} \mathrm{C}$ for $15 \mathrm{~s}$. The reactions were carried out using a CFX96 Real-Time System C1000 Thermal Cycler (Bio-RAD, USA). The relative expressions of genes were normalized to actin expression in each set of samples, according to the manufacturer's instructions, and the results were analyzed by matched software.

\section{Physical mapping of waterlogging tolerance loci and integration of genetic mapping with induced genes}

Waterlogging loci were identified using an $F_{2: 3}$ population from a cross between "HZ32" and "K12" using SSR markers [37], and the linked molecular markers were directly assigned to respective bacterial artificial chromosome (BAC) clones of maize inbred line B73 by searching in MaizeGDB http://www.maizegdb.org/. Subsequently, a physical map spanning the waterlogging tolerance loci was constructed in silico, based on the contig map.

The unigene sequences were assigned to the corresponding bacterial artificial chromosome (BAC) of maize inbred B73 using blastn, with an inclusion score $>100$ and E-value $<10^{-5}$, and then compared with the physical map of waterlogging tolerance loci to identify the co-localized unigenes.

\section{Results}

Construction of the forward subtractive cDNA library and identification of up-regulated genes

To identify genes induced at the late stage after waterlogging, a forward subtractive cDNA library was constructed. To gain an indication of the subtraction efficiency, $\gamma$-tubulin transcript abundance (primers: $\gamma$ tubulin -F TCTCCAGGGTCCTCCATTCC, $\gamma$-tubulin-R TGTCGTCCAACCTTACAACTCACT) was compared before and after subtraction by PCR. The abundance of this non-differentially expressed gene was estimated to be $\sim 2^{6}$ fold less in the subtracted cDNA populations (data not shown).
In the screening of clones in the SSH library, a replication of the reverse northern blot was carried out, with a biological replication of RNA samples, and the results were consistent for more than $98 \%$ of the clones, except for some variations of quantity.

A total of 471 of positive clones (Figure 1) were randomly chosen and sequenced. 465 ESTs (expressed sequence tags) longer than $100 \mathrm{bp}$ were obtained. The sizes of the original cDNA fragments ranged from 104 to $1081 \mathrm{bp}$, with an average size of approximately $332 \mathrm{bp}$.

\section{Annotation and functional cataloging of up-regulated genes}

A total of 296 unigenes were assembled from the 465 ESTs, of which 233 were singletons and 163 were contigs represented by 2-18 overlapping ESTs (Figure 2). The most abundant unigene comprised 18 ESTs and was annotated as nucleotide binding protein, followed by a unigene comprising 12 overlapped ESTs encoding a universal stress protein. The third most abundant unigene encoded alanine aminotransferase and comprised 10 ESTs (Additional file 1).

The annotation of 296 unigenes in GenBank indicated that $8.4 \%(25 / 296)$ of them had no homology in the database. The average length of these unigenes with no homology was significantly shorter than the length of those with hits in the database (209 bp compared to 344 bp). Subsequently, the 296 unigenes were assigned into 13 functional categories by a Gene Ontology assay (Figure 3). Although almost half (49.3\%) of the unigenes were clustered into "no significant homology" or "unclassified protein" categories, of the remainder, the main effects of waterlogging stress on cellular function at the late stage were signal transduction $(11.8 \%$ of categorized genes), carbon metabolism (7.1\% of categorized genes), and amino acid metabolism (6.4\% of categorized genes). Additionally, genes encoding transporter

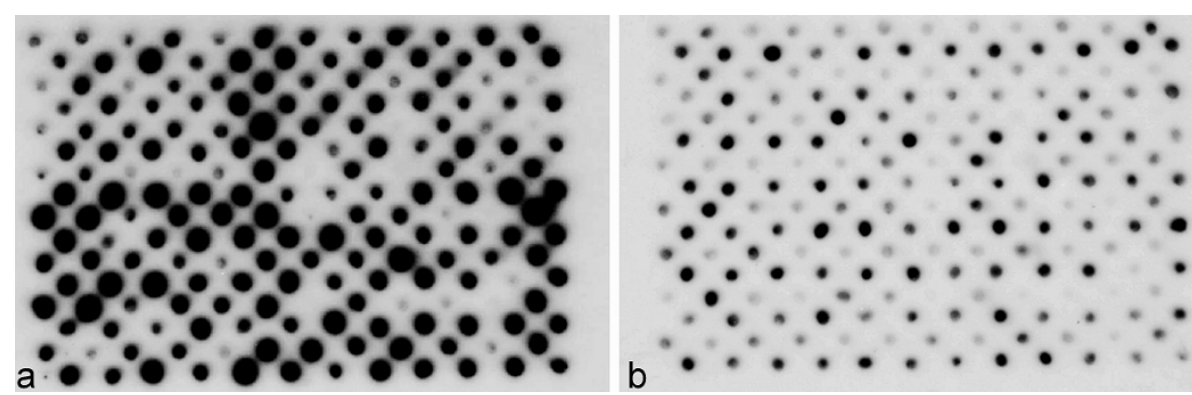

Figure 1 Screening by reverse Northern. One set of membranes is shown as an example. Each cDNA obtained from the SSH library was spotted onto a membrane. Membrane (a) and (b) were two identical membranes. Each blot was hybridized with ${ }^{32}$ P-labeled probes derived from $20 \mu \mathrm{g}$ of total RNA. Membrane A was hybridized with total RNA from waterlogging-treated samples as a probe, and B was hybridized with total RNA from the control as a probe. 


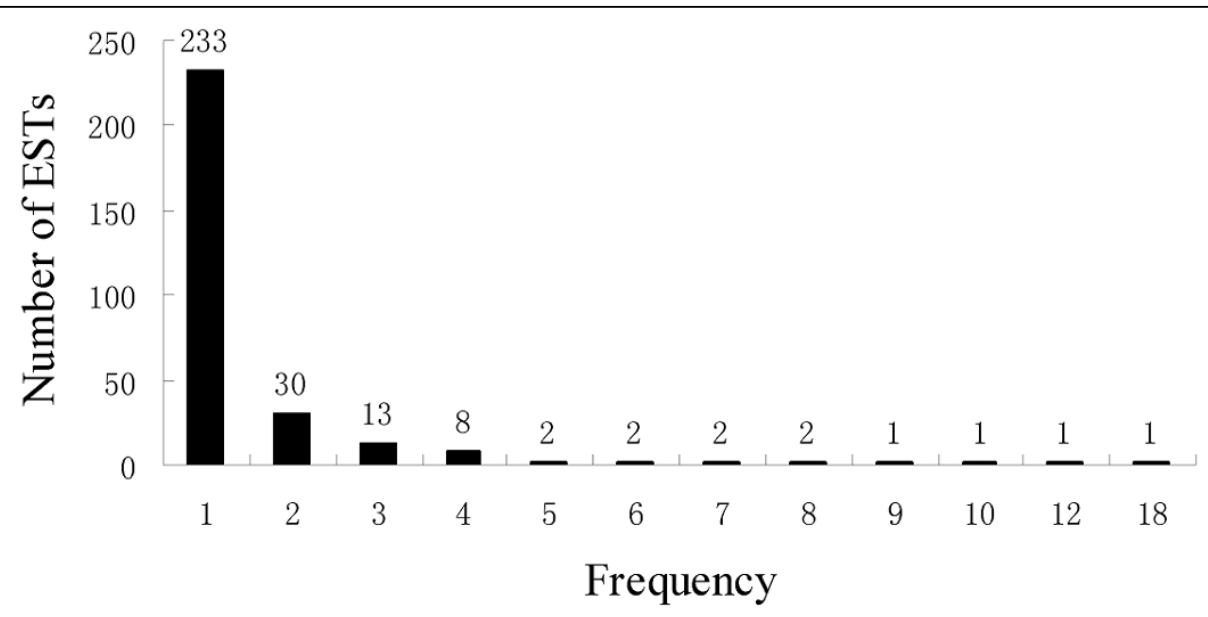

Figure 2 ESTs redundancy in the SSH library. Number of ESTs in each category is also presented at the top of each bar.

facilitation comprised $5.4 \%$. The remaining categorized unigenes (20.0\%) were assigned to oxidation-reduction, protein degradation, stress-induction, translation regulation, energy, secondary metabolism, and transcription regulation.

Unlike signal cascade-associated genes identified at the early stage of waterlogging stress, signal cascade-associated genes detected at the late stress stage can be classified into three significant subgroups; genes catalyzing reversible phosphorylation, hormone responsive genes, and genes involved in small molecule related pathways. For reversible phosphorylation, genes induced by waterlogging include lammer-type protein kinase, protein kinase APK1A, shaggy-related protein kinase, Mitogenactivated protein kinase (MAPK), protein phosphatase
$2 A$, protein phosphatase $2 C$, and diacylglycerol kinase. The hormone signal-associated genes up-regulated by waterlogging mostly encode plant hormone response factors, such as auxin response factor, coronatine-1insensitive protein 1, and ethylene-responsive protein. Small molecule signal transduction processes have been shown to have a well-established role under waterlogging stress. Several genes encoding small signal molecules were up-regulated at the late stage of waterlogging stress. Two genes encoding, respectively, calcium ion binding protein and calreticulin, which are known to be responsible for the balance of $\mathrm{Ca}^{2+}$ signal transduction, were identified in the forward library, indicating that the $\mathrm{Ca}^{2+}$ mediated signal cascade is potentially modulated by waterlogging in root cells. As well as genes encoding

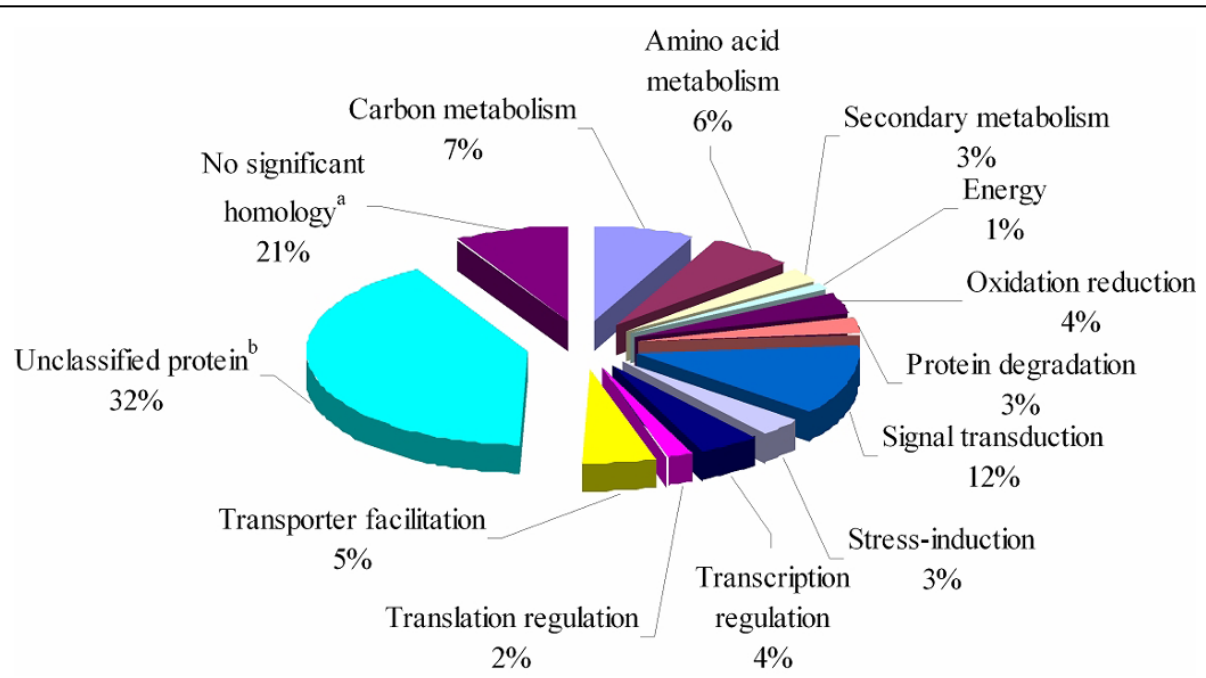

Figure 3 Functional categorization of induced genes. All 296 induced unigenes were functionally annotated using blastn and blastx at NCBI, and categorized based on GO annotation. Percentages of unigenes in each category are also presented at the top of each bar. ${ }^{a}$ These unigenes had no significant hits (score < 50) in blastn and blastx searches of GenBank. 'These unigenes matched proteins annotated as 'unknown protein' or 'hypothetical protein'. 
small GTP binding proteins, guanine nucleotide-binding protein, ADP-ribosylation factor 1, and ras-related protein were identified in the library, implying that the GTPase rheostat is involved in regulation of transcription at the late stage. A number of other genes that might be involved in signal transduction in response to waterlogging at the late stage were also found, including amelogenin precursor like protein, WD-repeat proteinlike, calpain-like protein, and TBC domain containing protein.

$16 \%$ unigenes $(48 / 296)$ that were included in the category "metabolism" can also be further clustered into three subgroups, carbon metabolism, amino acid metabolism, and secondary metabolism. For carbon metabolism, several genes encoding ANPs were identified, including sucrose synthase 1, glucose-6-phosphate 1dehydrogenase, glyceroldehyde-3-phosphate dehydrogenase, pyruvate kinase, and alcohol dehydrogenase, which are involved in multiple steps in glycolysis and fermentation pathways, which is consistent with results from previous studies in Arabidopsis and maize [4,45]. A gene encoding glucose-6-phosphate 1-dehydrogenase (G6PDH, EC 1.1.1.49) was induced under waterlogging stress. G6PDH controls the flux through a non-reversible limb of the oxidative pentose phosphate pathway and is responsible for generation of NADPH. Malic enzyme was also up-regulated and encodes a protonconsuming enzyme involved in a potential mechanism of preventing $\mathrm{pH}$ decline $[5,26]$. Nineteen unigenes encoding enzymes involved in amino acid metabolism, such as alanine aminotransferase, aspartate aminotransferase, isovaleryl-CoA dehydrogenase, ferredoxin-dependent glutamate synthase, and prolyl 4-hydroxylase alpha-2 were identified. It is interesting to note that an abundant unigene in this category was Alanine aminotransferase (comprising 12 ESTs), which showed significant induction by waterlogging stress. The category "secondary metabolism" comprised eight unigenes (3\%), encoding enzymes such as sirohydrochlorin ferrochelatase, isopentenyl-diphosphate delta-isomerase II, and dihydroflavonol-4-reductase. In this category, the gene encoding coproporphyrinogen III oxidase [EC 1.3.3.3] was also obtained in our forward SSH library, which catalyses oxidative decarboxylation of coproporphyrinogen III to proto-porphyrinogen IX in the heme.

Verification of SSH data by real-time quantitative RT-PCR To validate the results of the SSH library, the transcriptional level of 21 unigenes were examined by real time PCR using the same RNA for the library and two other biological replication of the RNA. Consistent with reverse northern blot, these unigenes exhibited $>2$ fold higher expression in response to waterlogging (Figure 4). However samples of prolyl 4-hydroxylase alpha-2 subunit did not yield a signal above the detection threshold, which revealed that the transcripts of this gene are present at about a $2^{-10}$ lower level than the housekeeping gene (Actin) (data not shown).

Additionally, real time PCR was performed for 19 of the 21 unigenes at each time point used in SSH library construction. The results (Figure 5) show that not every gene showed increased expression at each time point. For example, genes encoding acetyl-coenzyme A carboxylase, DNA-binding protein, ubiquitin-activating enzyme E1, and putative MAPK did not change significantly at $12 \mathrm{~h}$ and $16 \mathrm{~h}$, and showed increased expression at the two later time points. The gene encoding translation initiation factor eIF-2B showed increased expression at $12 \mathrm{~h}$ and $16 \mathrm{~h}$, and decreased to a normal level at $20 \mathrm{~h}$ and $24 \mathrm{~h}$. Other genes showed increased expression at all four time points.

\section{Integration of up-regulated genes with mapped QTLs}

QTLs for waterlogging tolerance were mapped to the B73 physical map [37]. This allowed us to determine whether the genes induced in the tolerant line HZ32 were located in the QTL regions.

Of the 296 unigenes, 198 were mapped to the maize physical map using blastn. The chromosomal locations of these genes are shown in Figure 6. Chromosomes 1 and 5 had the most ESTs (29 ESTs on each chromosome); chromosome 9 and 10 had the least (11 ESTs only, respectively).

63 (21.1\%) unigenes were in silico mapped to genomic regions harboring multi-trait or single-trait QTLs (Figure 7). A total of 21 (33.3\%) unigenes have no functional annotation, representing hypothetical proteins. Another 42 unigenes were genes related to various pathways, such as alanine aminotransferase, ADP-ribosylation factor, glucose-6-phosphate 1-dehydrogenase, acetyl-coenzyme A carboxylase, and alcohol dehydrogenase2 (Table $2)$. The co-localized unigenes were distributed on chromosomes $1,2,3,4,6$, and 10 , and more than half $(60 \%)$ were on chromosomes 1 and 4 .

In the study of QTLs for waterlogging tolerance, many regions were identified by more than one QTL. As a result, 33 ESTs (52.4\%) were mapped to regions identified by more than one QTL (2-7 QTLs).

\section{Discussion}

The reliability of the SSH library

At each step in the production of SSH data, variability can be introduced leading to potential errors. To control against negative results due to individual differences, samples were pooled from eight seedlings. To limit false positive genes, two biological replications of RNA from four time points were used to screen induced genes in the library by reverse northern blotting. The results 


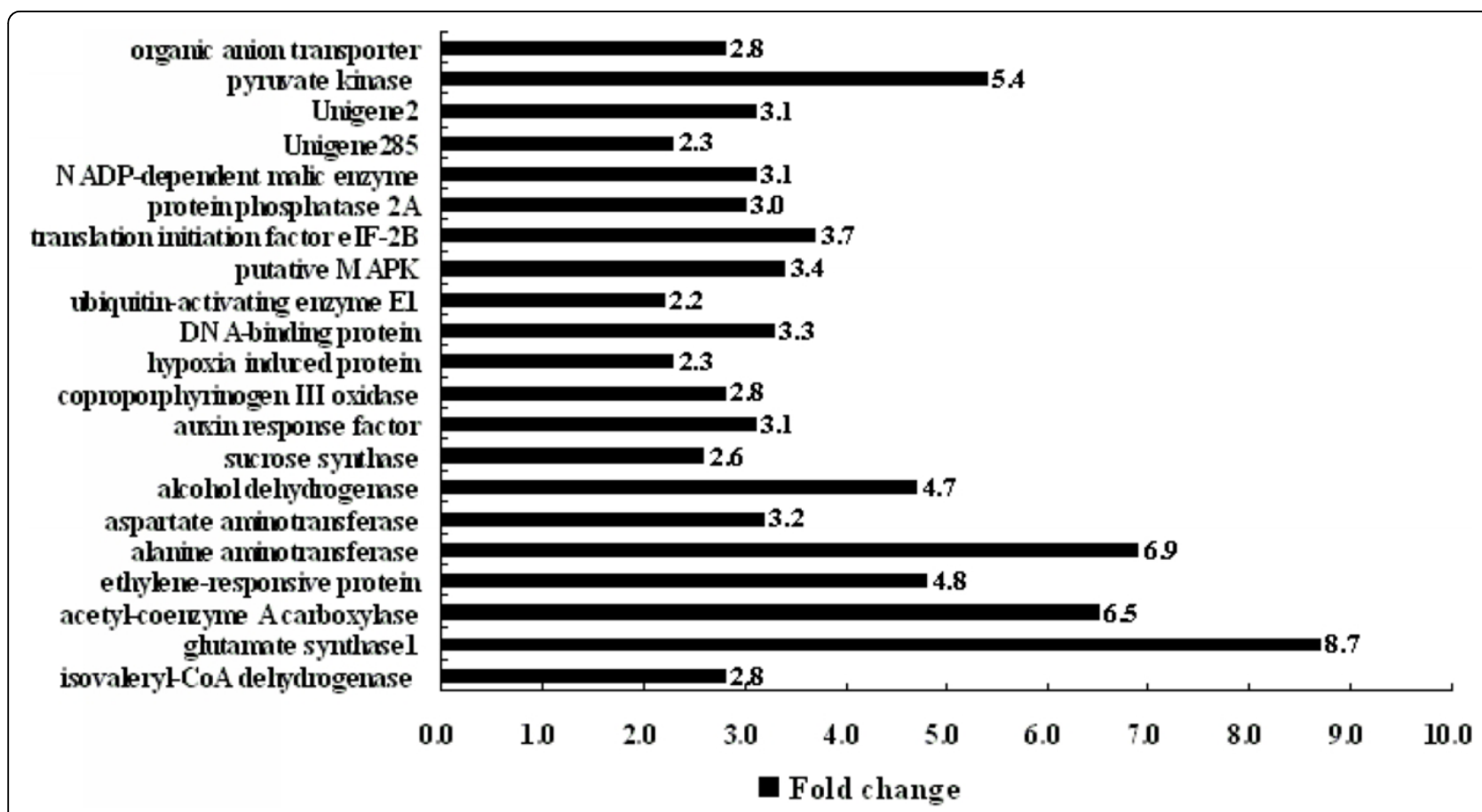

Figure 4 Verification of SSH results by real time PCR. The transcriptional levels of candidate genes was examined by real time PCR with three biological replications of pooled RNA. The fold change is the ratio of the expression of genes in the treatment compared to the control.

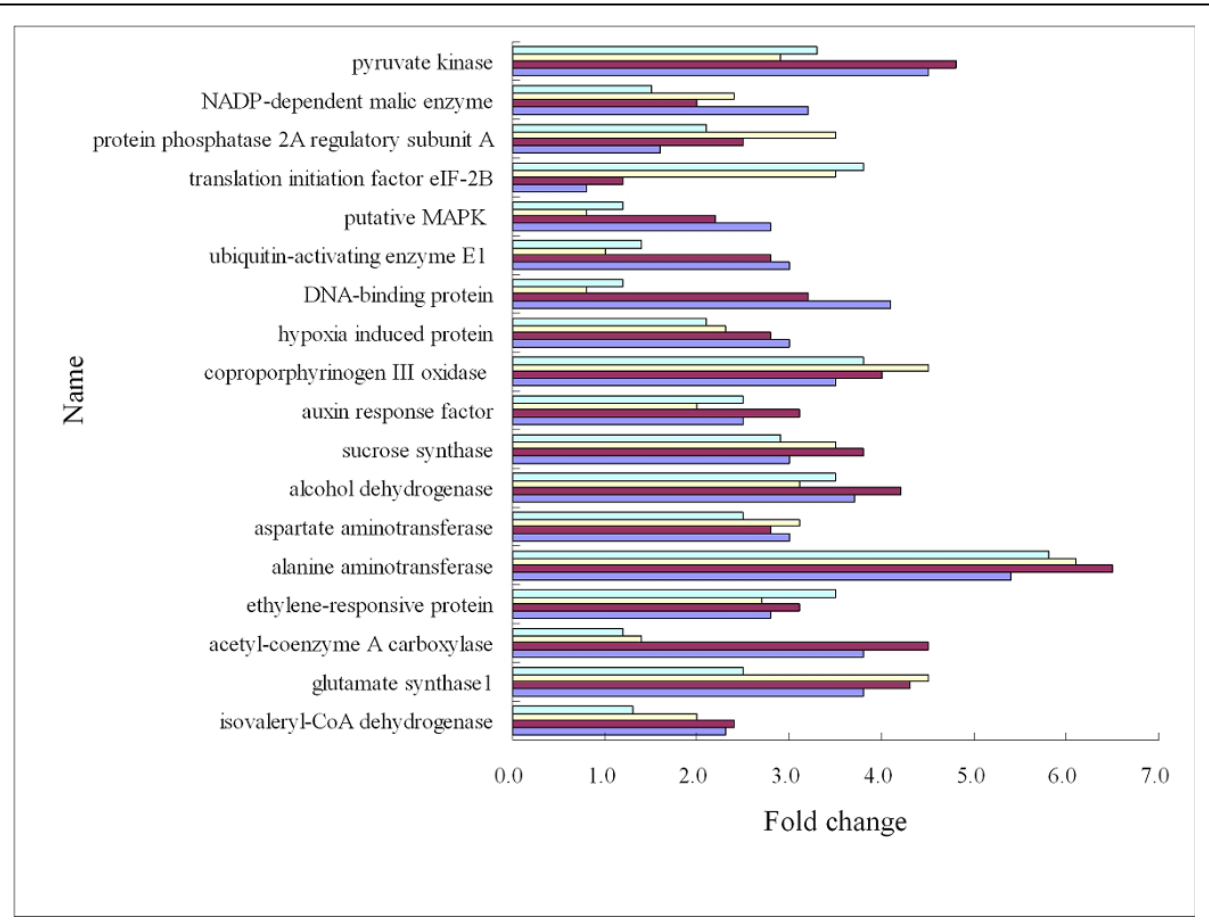

Figure 5 Verification of SSH results by real time PCR at each time point. The level of transcriptional of candidate genes was examined by real time PCR with three biological replications at each time point. The fold change is the ratio of the expression of genes in the treatment compared to the control. 


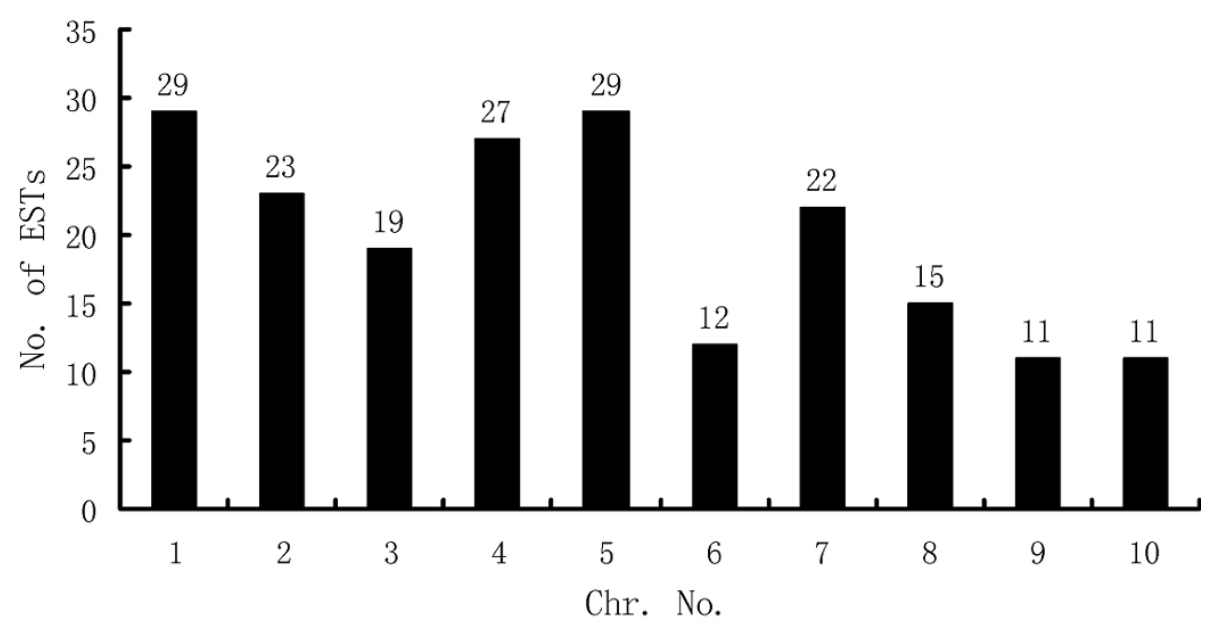

Figure 6 Distribution of induced unigenes on chromosomes. Numbers of unigenes on each chromosome are also presented at the top of each bar.

showed that although there was some biological variation, the data interpretation was not affected. The results were further confirmed by real time PCR experiments for 21 selected waterlogging-responsive genes with three biological replications of the RNA, including the same samples of RNA used in the SSH experiment and reverse northern blotting. The expression analysis of selected genes indicated that all were induced by waterlogging, as detected in the library, except for one gene with extremely low expression. The results of real time PCR performed at each time point revealed that not every gene was up-regulated during the entire late stage, which suggested that, although the expression profiles of genes identified in the SSH library were complicated, all the genes identified in the SSH library was induced at least one of the four time points.

\section{Crosstalk between various pathways}

The response to waterlogging is always via a network, and crosstalk takes place between different pathways. This idea was supported by the identification of genes classified into different categories at the late stage of waterlogging. Although the genes identified were categorized into nine categories by functional annotation, there was no clear boundary among these categories. Based on the results revealed by genes obtained from the SSH library, some possible links between the categories can be deduced (Figure 8).

\section{Signal transduction events and crosstalk among various pathways}

Signal cascades occurring in maize roots subjected to waterlogging provide significant clues for understanding the regulation of gene expression. In this study, similar to the results revealed by both Klok and Liu in
Arabidopsis under hypoxia stress [7,42], genes related to various signal cascades identified in the SSH library were overrepresented at the late stage. Although genes involved in signal transduction were also found in the previous study at the early stage (1-8 h), they were completely different [38-40]. These genes mainly act in three different signal pathways. For example, a gene encoding putative mitogen-activated protein kinase (MAPK) was up-regulated under waterlogging. MAPK is a signal molecule mediating protein phosphorylation directly or indirectly [46]. Plant MAPK cascades have been implicated in the development and responses to stress. In Arabidopsis, stress-responsive MAP kinase (MAPK) 6 leads to phosphorylation of ACC synthase (ACS) [47], which is related with accumulation of ethylene, a well known molecule in the response to waterlogging [48]. It was reported that the formation of aerenchyma in roots, the key response for survival of prolonged waterlogging after $24 \mathrm{~h}$, was triggered by ethylene. Furthermore, there was a breakthrough in the study of plant adaptation to anaerobiosis, which was closely related to ethylene. Map-based cloning and characterization of two major QTLs for tolerance of flooding in rice revealed that both Snorkel [49-51] and Sub 1A [25,52] represented genes encoding ethylene-responsive factor-type transcription factors and are connected to gibberellin biosynthesis or signal transduction. However, the two genes regulated different mechanisms of adaptation to flooding; escape by elongation or remaining stunted under water until the flood recedes [53]. Thus, the results suggested that induction of MAPK in roots subjected to waterlogging could promote a MAPK cascade to regulate ethylene biosynthesis, which in turn regulates plant hormone cascades, finally resulting in modulation of morphological adaptation. 


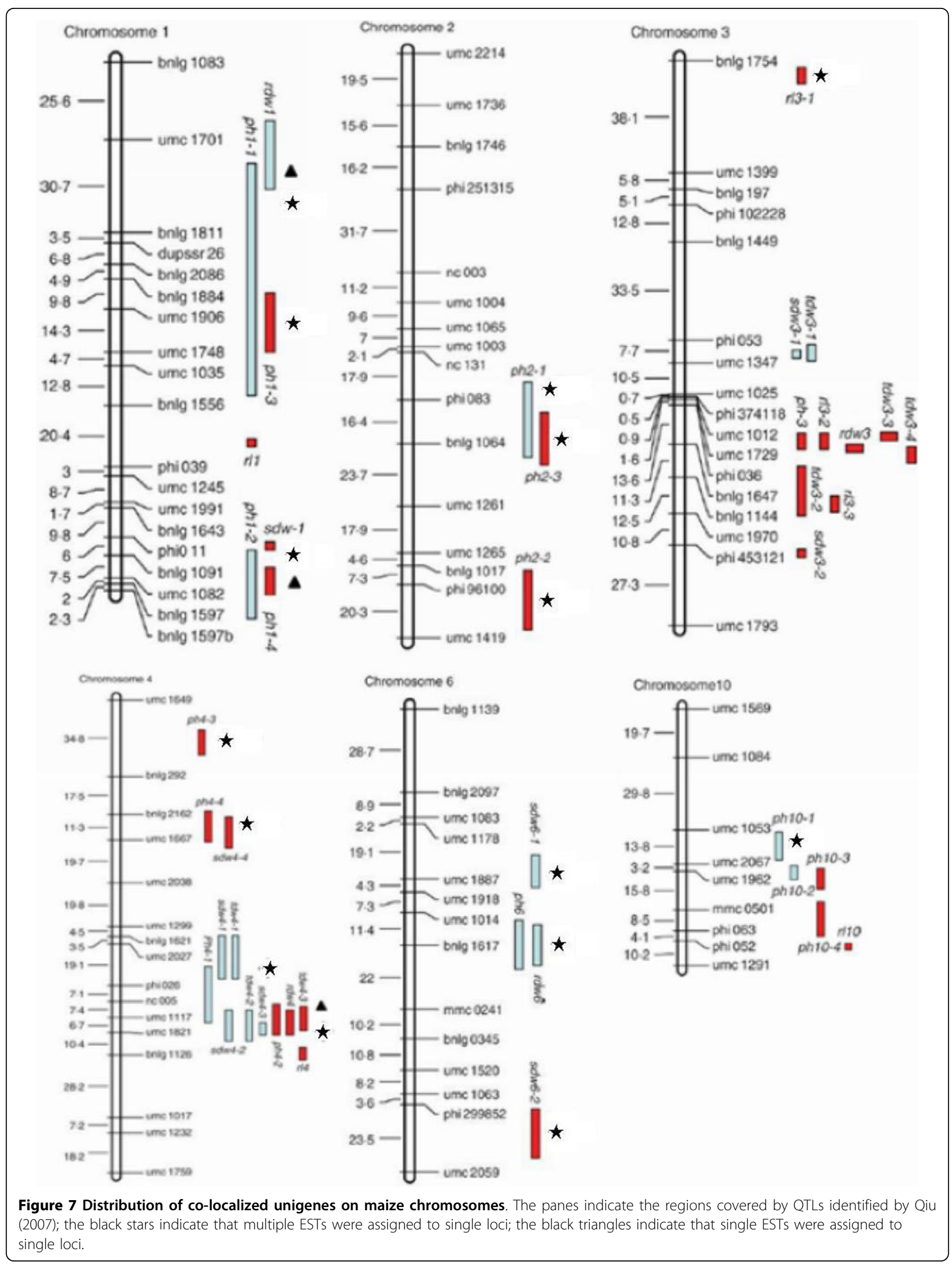


Table 2 QTL information for co-localized genes in the forward SSH library

\begin{tabular}{|c|c|c|c|c|}
\hline Chr. No. & Unigene & $I^{a}$ & $\mathrm{QTL}^{\mathrm{b}}$ & Annotation $^{c}$ \\
\hline 1 & 278 & $\mathrm{HO} 068217$ & Ph1-1 & calpain-like protein \\
\hline 1 & 245 & HO068192 & Ph1-1 & protein kinase $\mathrm{C}$ inhibitor \\
\hline 1 & 118 & HO068078 & Ph1-1 & WD-repeat protein-like \\
\hline 1 & 281 & HO068220 & Ph1-1 & $40 \mathrm{~S}$ ribosomal protein \\
\hline 1 & 78 & HO068280 & Ph1-1 & ADP-ribosylation factor 1 \\
\hline 1 & 292 & HO068229 & Ph1-1 & pyruvate dehydrogenase E1 \\
\hline 1 & 160 & HO068116 & Ph1-1 & $26 \mathrm{~S}$ proteasome regulatory particle non-ATPase subunit5 \\
\hline 1 & 22 & HO068177 & $\mathrm{Ph} 1-1 / \mathrm{Ph} 1-3$ & vacuolar protein sorting 26 \\
\hline 1 & 1 & HO068150 & $\mathrm{Ph} 1-1 / \mathrm{Ph} 1-3$ & alanine aminotransferase 2 \\
\hline 1 & 10 & H0068069 & $\mathrm{Ph} 1-1 / \mathrm{Ph} 1-3$ & alanine aminotransferase 2 \\
\hline 1 & 210 & HO068162 & $\mathrm{Ph} 1-1 / \mathrm{Ph} 1-3$ & wound responsive protein \\
\hline 1 & 115 & HO068075 & Ph1-1/Ph1-3 & putative glutathione peroxidase \\
\hline 1 & 116 & HO068076 & $\mathrm{Ph} 1-1 / \mathrm{Ph} 1-3$ & putative glutathione peroxidase \\
\hline 1 & 13 & HO068100 & $\mathrm{Ph} 1-1 / \mathrm{Ph} 1-3$ & hypothetical protein \\
\hline 1 & 102 & HO068062 & $\mathrm{Ph} 1-1 / \mathrm{Ph} 1-3$ & succinyl-CoA ligase alpha-chain 2 \\
\hline 1 & 100 & HO068060 & $\mathrm{Ph} 1-1 / \mathrm{Ph} 1-3$ & vacuolar ATP synthase \\
\hline 1 & 52 & HO068258 & $\mathrm{Ph} 1-1 / \mathrm{Ph} 1-3$ & hypothetical protein \\
\hline 1 & 34 & HO068239 & Ph1-1/rdw1 & putative cystatin \\
\hline 1 & 215 & HO068166 & $\mathrm{Ph} 1-2 / \mathrm{ph} 1-4$ & tryptophanyl-tRNA synthetase \\
\hline 1 & 139 & HO068099 & sdw-1 & hypothetical protein \\
\hline 1 & 140 & H0068101 & sdw-1 & hypothetical protein \\
\hline 2 & 102 & H0068062 & Ph2-1 & succinyl-CoA ligase alpha-chain 2 \\
\hline 2 & 25 & HO068205 & Ph2-1 & sirohydrochlorin ferrochelatase \\
\hline 2 & 198 & HO068147 & $\mathrm{Ph} 2-1 / \mathrm{Ph} 2-3$ & $60 \mathrm{~S}$ ribosomal protein \\
\hline 2 & 23 & HO068187 & $\mathrm{Ph} 2-1 / \mathrm{Ph} 2-3$ & topoisomerase-like protein \\
\hline 2 & 145 & HO068106 & Ph2-2 & pyruvate kinase \\
\hline 2 & 137 & HO068097 & Ph2-2 & hypothetical protein \\
\hline 2 & 138 & HO068098 & Ph2-2 & hypothetical protein \\
\hline 2 & 171 & HO068125 & $\mathrm{Ph} 2-2$ & hypothetical protein \\
\hline 2 & 117 & HO068077 & Ph2-2 & tRNA-splicing endonuclease subunit \\
\hline 3 & 15 & HO068115 & $\mathrm{Rl} 3-1$ & hypothetical protein \\
\hline 3 & 164 & HO068119 & $\mathrm{Rl3}-1$ & NADP-dependent malic enzyme \\
\hline 4 & 50 & HO068256 & Ph4-1/sdw4-1/tdw4-1 & CAAX prenyl protease 1 \\
\hline 4 & 194 & HO068144 & Ph4-1/sdw4-1/tdw4-1 & hypothetical protein \\
\hline 4 & 176 & HO068128 & Ph4-1/sdw4-1/tdw4-1 & glyceroldehyde-3-phosphate dehydrogenase GAPC3 \\
\hline 4 & 135 & HO068095 & Ph4-1/sdw4-1/tdw4-1 & CAAX prenyl protease 1 \\
\hline 4 & 136 & H0068096 & Ph4-1/sdw4-1/tdw4-1 & CAAX prenyl protease 1 \\
\hline 4 & 8 & HO068291 & Ph4-1/sdw4-1/tdw4-1/sdw4-2/tdw4-2/ph4-2/tdw4-3 & CAAX prenyl protease 1 \\
\hline 4 & 232 & HO068180 & Ph4-3 & pollen signalling protein with adenylyl cyclase activity \\
\hline 4 & 247 & HO068194 & Ph4-3 & pollen signalling protein with adenylyl cyclase activity \\
\hline 4 & 7 & HO068281 & Ph4-3 & pollen signalling protein with adenylyl cyclase activity \\
\hline 4 & 162 & HO068118 & Ph4-3 & hypothetical protein \\
\hline 4 & 244 & HO068191 & Ph4-3 & CAND1 binding (CAND1) \\
\hline 4 & 78 & HO068280 & $\mathrm{Ph} 4-4 / \mathrm{sdw} 4-4$ & ADP-ribosylation factor 1 \\
\hline 4 & 202 & HO068153 & $\mathrm{Ph} 4-4 / \mathrm{sdw} 4-4$ & hypothetical protein \\
\hline 4 & 9 & HO068295 & Ph4-4/sdw4-4 & hypothetical protein \\
\hline 4 & 219 & HO068168 & Ph4-4/sdw4-4 & nucleotide binding protein \\
\hline 4 & 17 & HO068131 & Sdw4-3/sdw4-2/tdw4-2/ph4-2/tdw4-3 & alcohol dehydrogenase 2 \\
\hline 4 & 236 & HO068184 & Sdw4-3/sdw4-2/tdw4-2/ph4-2/tdw4-3 & hypothetical protein \\
\hline 4 & 177 & HO068129 & Sdw4-3/sdw4-2/tdw4-2/ph4-2/tdw4-3 & hypothetical protein \\
\hline 6 & 207 & HO068158 & $\mathrm{ph} 6 / \mathrm{rdw} 6 / \mathrm{Sdw6}-2$ & hypothetical protein \\
\hline
\end{tabular}


Table 2 QTL information for co-localized genes in the forward SSH library (Continued)

\begin{tabular}{ccccc}
\hline 6 & 287 & H0068224 & ph6/rdw6/Sdw6-2 \\
ph6/rdw6/Sdw6-2 & CCR4-NOT transcription complex subunit 6 \\
6 & 129 & H0068088 & Sdw6-1/Sdw6-2 & hypothetical protein \\
6 & 178 & H0068130 & Sdw6-1/Sdw6-2 & vacuolar ATP synthase subunit B \\
6 & 109 & H0068068 & Sdw6-1/Sdw6-2 & vacuolar ATP synthase subunit B \\
6 & 110 & H0068070 & Sdw6-2 & hypothetical protein \\
6 & 230 & H0068178 & Sdw6-2 & transport protein particle subunit \\
6 & 161 & H0068117 & Sdw6-2 & MPK17-1 - putative MAPK \\
6 & 96 & H0068293 & Ph10-1 & hypothetical protein \\
10 & 13 & H0068100 & Ph10-1 & glucose-6-phosphate 1-dehydrogenase \\
10 & 234 & H0068182 & Ph10-1 & acetyl-coenzyme A carboxylase \\
10 & 141 & H0068102 & hh10-1 & hypothetical protein \\
10 & 72 & H0068275 &
\end{tabular}

accession numbers of unigenes.

b The QTLs were identified by Qiu, and sdw = shoot dry weight; ph = plant height; rl = root length; rdw = root dry weight; tdw = total dry weight. For all the QTL names, the first number following the letters represents the chromosome locations of the QTL and the second number represents the orders of the QTL located on the same chromosome by the same trait.The sequence was searched in MaizeGDB using blastn of an inclusion score $>100$ and $\mathrm{E}$-value $<10^{-5}$.

' The annotation was obtained by a similarity search using blastn and blastx at NCBI.

A gene encoding coproporphyrinogen III oxidase [EC 1.3.3.3] was obtained in our forward SSH library, which catalyses oxidative decarboxylation of coproporphyrinogen III to proto-porphyrinogen IX in the heme. Previous studies suggested that hemoglobin was up-regulated under hypoxia in barley, maize roots, and embryos [54] and has an important role in survival at the late stage of waterlogging. Over-expression of hemoglobin in maize could actually enhance root growth [55], as was found in other species [56,57]. Hemoglobin may serve as an $\mathrm{O}_{2}$ sensor [58], or act as an $\mathrm{O}_{2}$ carrier, as in animal cells in stressed tissues [59], to preserve oxygen-obligated metabolism, such as ethylene synthesis, in plants. At this late stage, synthesis of hemoglobin could be an important step in activating the next stage in the response to waterlogging.

A gene encoding prolyl 4-hydroxylase $(\mathrm{P} 4 \mathrm{H})$ [1.14.11.2], another oxygen sensor [60], was up-regulated in maize roots under waterlogging. $\mathrm{P} 4 \mathrm{H}$ has been proven to control a transcription factor (hypoxia-inducible heterodimeric transcription factor, HIF), a global regulator of hypoxia, through proline hydroxylation in various mammals [61]. Prolyl 4-hydroxylase targets proline residues of HIF for rapid ubiquitination and proteasomal degradation when oxygen is available. HIF is accumulated when oxygen is limited $[62,63]$. However, there has been little evidence of a role of $\mathrm{P} 4 \mathrm{H}$ in the regulation of the hypoxia response by modulating the expression of specific transcription factors in plants [64]. A recent study reported that overexpression of AtP4H1 in Arabidopsis could mediate and mimic the low oxygen response [65]. In maize, the $\mathrm{P} 4 \mathrm{H}$ gene has not been cloned, possibly due to its low level of expression. The advantage of the $\mathrm{SSH}$ technique for accumulating low abundance transcripts has resulted in the identification of a $\mathrm{P} 4 \mathrm{H}$ transcript in our library. The induction of $\mathrm{P} 4$
$H$ under waterlogging stress implied the possible participation of the $\mathrm{P} 4 \mathrm{H}$ signaling pathway at the late stage of waterlogging stress.

Although the two induced genes discussed above were categorized in "transporter activity" or "amino acid metabolism", they are also related to signaling events. This implies that signal transduction is not linear, but that crosstalk exists among different biochemical pathways, such as hemoglobin and $\mathrm{P} 4 \mathrm{H}$.

Previous studies have reported that signal transduction events mostly occur at the early stage of waterlogging [14]. To our surprise, many (more than 11\%) of the induced genes obtained in the library were involved in various signaling pathways. This suggested that the response to waterlogging at the late stage was more complicated than was expected. It was reported that the third stage (24-48 h) was important for survival of prolonged exposures to low oxygen tension, and involves the formation of aerenchyma in the roots [5], which was not a direct consequence of oxygen deficiency, but was presumably triggered by stage 1 and/or stage 2 genes [66].

We propose that the response to waterlogging in the roots of maize seedlings occurs in two phases (defense and adaptation). At the early stage, it is most important that plants can sense the lack of oxygen around the root system and trigger initial changes to gene expression, while at the late stage, signal transduction pathways different from the early stage should be activated to regulate the tolerance mechanism for survival under prolonged waterlogging.

\section{Crosstalk between carbon utilization and amino acid metabolism}

Carbon utilization is a well-known mechanism regulated under waterlogging. Many studies revealed that genes 


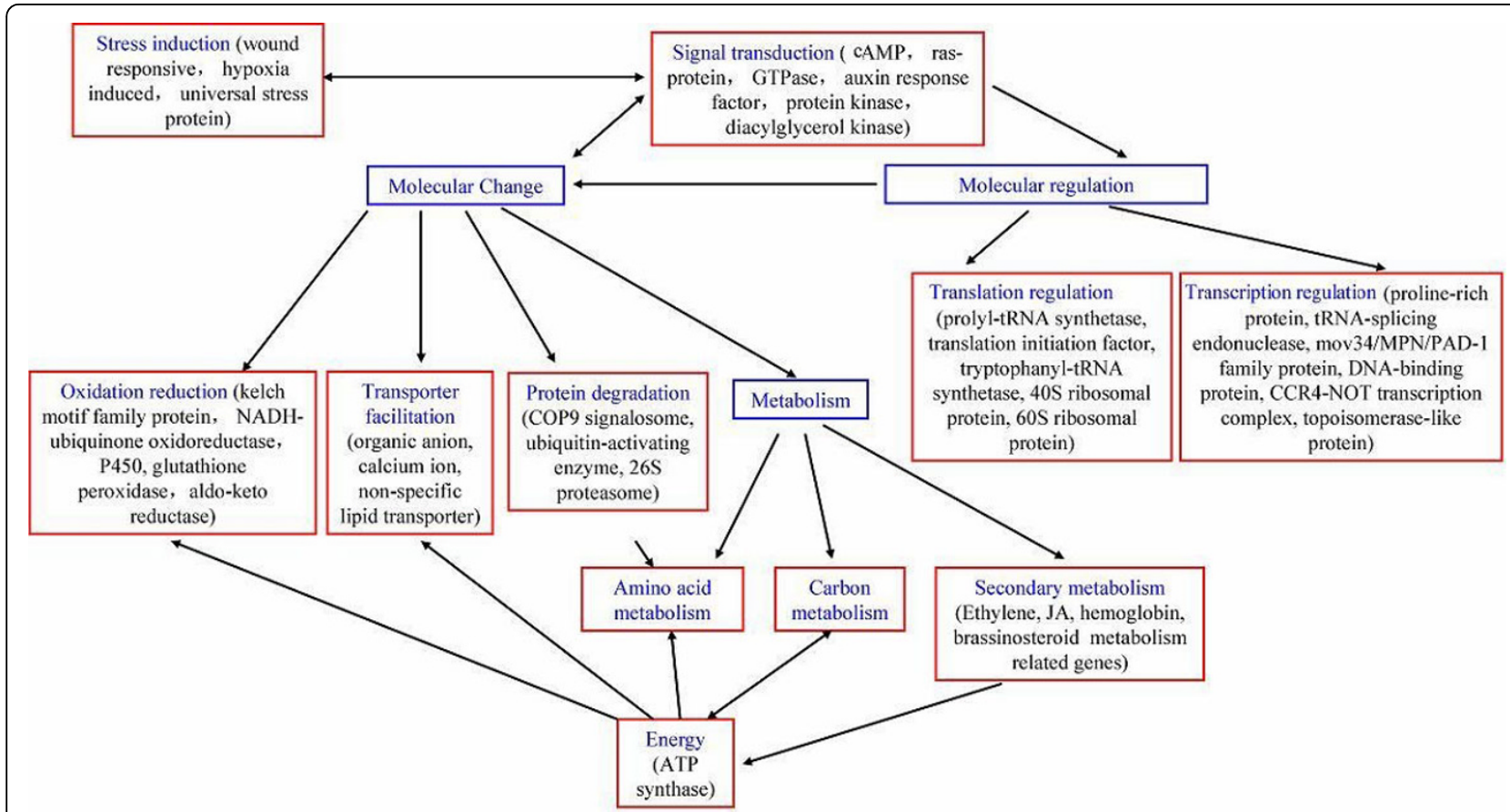

Figure 8 Crosstalk between the categories of induced genes. Red frames represent categories with functional annotation; blue characters for names of categories and black ones for genes; the bidirectional arrow represents the presence of crosstalk.

responsible for carbon utilization were induced in response to hypoxia in many species. Consistent with results from previous expression profiling and proteomic studies in rice [41,67] and Arabidopsis [7,42,43,68], a number of genes involved in the glycolysis pathway were identified, implying that glycolysis is still active at the late stage under waterlogging, for supply of carbon source and energy $[66,69,70]$. In theory, breakdown of carbohydrates is the main pathway of carbon flux and energy supply. Actually, intermediates from lipid and protein degradation also act as important carbon sources entering glycolysis under waterlogging.

Many genes encoding proteins or enzymes involved in degradation of lipids and proteins were identified in our SSH library, which supports the hypothesis mentioned above. Although genes involved in protein degradation were identified at the early stage [38-40], it is interesting that more than $3 \%$ of the genes induced by waterlogging were related with protein degradation, such as COP9 signalosome complex subunit 3, ubiquitin-conjugating enzyme, ubiquitin-activating enzyme E1, and 26 S proteasome regulatory particle non-ATPase. The results implied that degradation of aerobic proteins would help decrease the consumption of oxygen, and abundant free amino acids should be derived at the same time. Free amino acids have two destinations, protein synthesis and amino metabolism. Hypoxia can repress overall protein synthesis in plants [4]. Accordingly, accumulated free amino acids from protein degradation should act as substrates in amino acid metabolism.

Importantly, the gene encoding Alanine aminotransferase (AlaAT; E.C. 2.6.1.2), which is involved in amino acid metabolism, was induced in root cells of maize seedlings under waterlogging conditions. AlaAT catalyzes reversible transfer of an amino group from alanine to 2-oxoglutarate to form pyruvate and glutamate. The induction of AlaAT under hypoxia, accompanied by the accumulation of alanine, has been reported in barley $[71,72]$, rice [73], soybean [74], and Arabidopsis [7,75]. In Arabidopsis, a study on an AlaAT1 mutant (alaat1-1) demonstrated that AlaAT primarily catalyzes the breakdown of alanine under hypoxia stress, instead of synthesis of alanine [76]. In other words, there are other pathways for the accumulation of alanine that do not include the AlaAT pathway.

The gene encoding ferredoxin-dependent glutamate synthase (GS) was also up-regulated in response to waterlogging at the late stage. GS is involved in the GS/ GOGAT cycle, which is used to store carbon and nitrogen, and is responsible for regenerating glutamate [77]. Glutamate has been shown to be a critical product for regulation of cytoplasmic $\mathrm{pH}$. It is catalyzed by glutamate decarboxylase (GAD; EC 4.1.1.1 [EC] 5), consuming a proton and synthesizing GABA $[30,78,79]$. GABA can be converted to succinate and enter carbon metabolism. This metabolic pathway involves GABA-T and 
SSADH, and this route for glutamate carbon to enter the tricarboxylic acid cycle (TCA cycle) is called the GABA shunt. Ala is synthesized from pyruvate in this process, which suggests the GABA shunt is responsible for accumulation of Ala under waterlogging conditions.

Considering of the information above, it is possible that Ala can be accumulated from protein degradation and the GABA shunt, and that there is a cycle between pyruvate and Ala. In this study, a gene encoding aspartate aminotransferase was shown to be induced under waterlogging, which can generate Glu and OAA from Asp and 2-oxoglutarate. OAA can be converted to malate, which has a critical role in regulation of cytoplasmic $\mathrm{pH}$, catalyzed by malic enzyme, which was also upregulated in this study.

It seems that in root cells of maize seedlings at the late stage of waterlogging stress, amino acid metabolism has two main roles (Figure 9), a) generating Glu and Ala, which are critical for regulation of cytoplasmic $\mathrm{pH}$; and $b$ ) break down of carbon skeletons and generating intermediates for energy metabolism.

Recently, most studies of carbon unitilization for flooding tolerance response focused on $p d c$ and $a d h$ in this complicated cycle of pathways. It was not surprising that phenotypic analysis of over-expression of $p d c$ or $a d h$ in rice [14,80,81], arabidopis [82], cotton [83], and other species has provided different conclusions. Based on the results revealed this study, genes involved in protein degradation and amino acid synthesis are ideal candidate genes that enhance flooding tolerance of plants along with $p d c / a d h$.

\section{Mapping differentially expressed genes in the response to waterlogging}

For this and other studies, the ultimate aim is to clone the genes responsible for tolerance to waterlogging. The classic approach is map-based cloning. However, the development of molecular markers and genotyping a mapping population is very expensive and time consuming. On the other hand, a large number of genes involved in the response to waterlogging can be obtained using the technique of SSH. The candidate gene approach is thus more convenient and cost saving. Localized on a QTL linkage map, they may be seen as positional candidate genes for further investigation by functional analysis.

Therefore, the latter strategy was adopted to analyze all 296 up-regulated unigenes. Only 63 (21.1\%) unigenes were located in the regions identified by QTLs. There could be two reasons for this. First, the genome sequence of maize is not perfect and contains many gaps http://www.maizesequence.org, and significant differences of sequence exist among in maize inbred lines [84-86]. These could be responsible for the failure of up

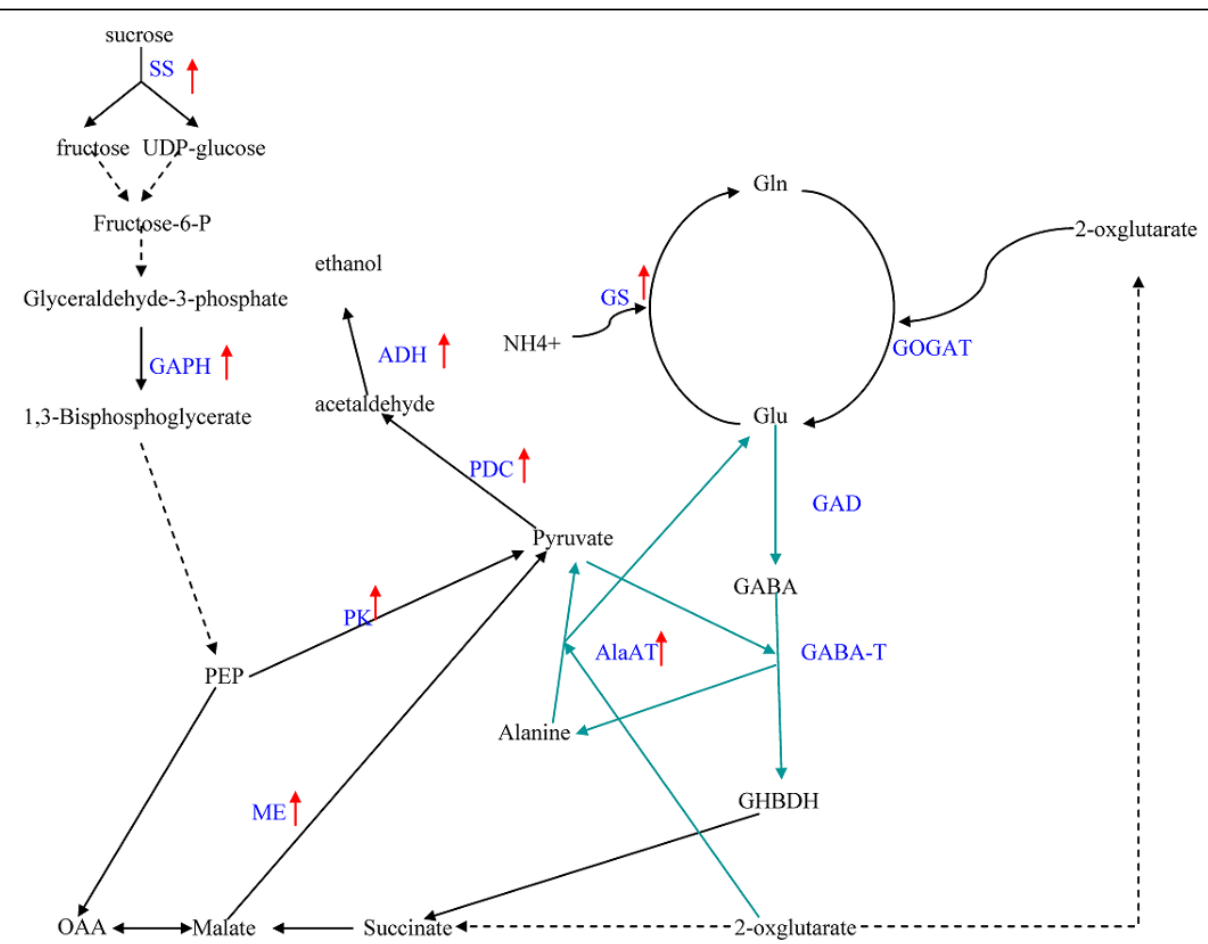

Figure 9 The crosstalk between carbon and amino acid metabolism. Black characters represent products in the pathway; blue characters represent enzymes involved in the pathway; the red arrow represents the gene that was identified to be induced in our library. 
to $33 \%$ of the unigenes to be localized on the map. Second, the fact that an EST was not co-located with a QTL does not imply that the EST was not important for waterlogging tolerance, because the lack of functional polymorphism between parental alleles of a gene can result in the absence of a QTL.

The co-located unigenes should be further verified before in-depth study. Due to the limited mapping resolution used in the previous study, the positions of these identified QTLs could not be accurately determined, which can cause false positives for the candidate gene approach. Further detailed genetic analysis is needed to determine whether the genes in these regions represent candidate genes for these QTLs. Nevertheless, this is the first step in combining expression profiles and QTL mapping in the study of the tolerance of waterlogging. It is complementary to map based cloning and could used for marker-assisted selection in breeding.

\section{Conclusion}

To gain an insight into how the roots of maize seedlings respond to waterlogging at the late stage, we carried out gene expression profiling at four time points $(12 \mathrm{~h}$, $16 \mathrm{~h}, 20 \mathrm{~h}$, and $24 \mathrm{~h}$ ) after waterlogging treatment using tolerant inbred line HZ32. Annotation and analysis based on gene ontology terms suggested that waterlogging affected a broad spectrum of functional categories.

At the late stage of waterlogging, amino acid metabolism plays an important role related to protein degradation and carbon metabolism. It is thought to be involved in regulation of cytoplasmic $\mathrm{pH}$ and breakdown of carbon skeletons for the supply of energy. Signal transduction is still active and is different from those signaling pathways induced in early stages, possibly because of the need to regulate the tolerance mechanism for survival under prolonged waterlogging. We propose that the response to waterlogging should be conceptually divided into two stages: defense and adaption. The new genes related to signal transduction identified in this study might perform key roles in regulating the response to waterlogging at the late stage and provide new insights into the response to waterlogging in maize.

A total of 63 candidate genes for waterlogging tolerance were validated by in silico mapping through a candidate gene approach. These genes might be important candidates for further breeding of waterlogging-tolerant crops, but will require further verification.

The identification of specific genes affecting complex traits is always one of the most difficult tasks in genetics. By studying which genes are induced at the late stage in response to waterlogging in the roots of maize seedlings, we have provided the basis for further investigation in this field. Sense/antisense over-expression of these genes in transgenic plants could be used to identify their contribution to waterlogging tolerance.

\section{Additional material}

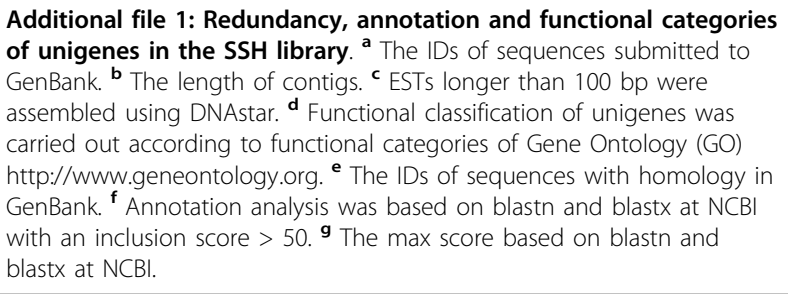

\section{Acknowledgements}

We sincerely thank Fazhan Qiu, Bin Tang and Ming Wang for their suggestive opinions in writing this paper. This work is supported by the HiTech Research and Development program of China (2008AA10Z112, 2006AA10A106) and National Science Foundation of China (30771352).

\section{Authors' contributions}

$Y Z$ conceived of the study and participated in its design. ZZ was involved in designing and planning the work, and in interpreting the results. $X Z$ carried out most of the work and drafted the manuscript. YJ participated the screening of the library and real time PCR analysis. LL helped with the electronic mapping. All authors have read and approved the final manuscript.

Received: 22 October 2009 Accepted: 25 August 2010

Published: 25 August 2010

\section{References}

1. Visser EJW, Voesenek LACJ, Vartapetian BB, Jackson MB: Flooding and Plant Growth. Ann Bot 2003, 91:107-109.

2. Armstrong W: Aeration in higher plants. Adv Bot Res 1979, 7:225-232.

3. Erdmann B, Hoffmann P, Wiedenroth EM: Changes in the Root System of Wheat Seedlings Following Root Anaerobiosis I. Anatomy and Respiration in Triticum aestivum L. Ann Bot 1986, 58:597-605.

4. Sachs MM, Freeling M, Okimoto R: The anaerobic proteins of maize. Cell 1980, 20:761-767.

5. Sachs MM, Subbaiah CC, Saab IN: Anaerobic gene expression and flooding tolerance in maize. J Exp Bot 1996, 47:1-15.

6. Chang WWP, Huang $L$, Shen $M$, Webster C, Burlingame AL, Roberts JKM: Patterns of protein synthesis and tolerance of anoxia in root tips of maize seedlings acclimated to a low-oxygen environment, and identification of proteins by mass spectrometry. Plant Physiol 2000, 122:295-318.

7. Klok EJ, Wilson IW, Wilson D, Chapman SC, Ewing RM, omerville SC, Peacock WJ, Dolferus R, Dennis ES: Expression profile analysis of the lowoxygen response in Arabidopsis root cultures. Plant Cell 2002, 14:2481-2494.

8. Tsuji $H$, Nakazono M, Saisho D, Tsutsumi N, Hirai A: Transcript levels of the nuclear-encoded respiratory genes in rice decrease by oxygen deprivation: evidence for involvement of calcium in expression of the alternative oxidase 1a gene. FEBS Lett 2000, 471:201-204.

9. Baxter-Burrell A, Chang R, Springer PS, Bailey-Serres J: Gene and enhancer trap transposable elements reveal oxygen deprivation-regulated genes and their complex patterns of expression in Arabidopsis. Ann Bot 2003, 91:129-141.

10. Baxter-Burrell A, Yang Z, Springer PS, Bailey-Serres J: ROPGAP4-dependent Rop GTPase rheostat controls of Arabidopsis oxygen deprivation tolerance. Science 2002, 296:2026-2028.

11. Snedden WA, Fromm H: Calmodulin as a versatile calcium signal transducer in plants. New Phytol 2001, 151:35-66. 
12. Subbaiah CC, Sachs MM: Maize cap1 encodes a novel SERCA-type calcium ATPase with a calmodulin-binding domain. J Biol Chem 2000, 275:21678-21687.

13. Drew MC, He CJ, Morgan PW: Programmed cell death and aerenchyma formation in roots. Trends Plant Sci 2000, 5:123-127.

14. Dennis ES, Dolferus $R$, Ellis M, Rahman M, Wu Y, Hoeren FU, Grover A, Ismond KP, Good AG, Peacock WJ: Molecular strategies for improving submergence tolerance in plants. J Exp Bot 2000, 51:89-97.

15. Hwang SY, VanToai TT: Abscisic acid induces anaerobiosis tolerance in corn. Plant Physiol 1991, 97:593-597.

16. Newman DS, Smit BA: The influence of leaf water status and ABA on leaf growth and stomata of Phaseolus vulgaris with hypoxic roots. J Exp Bot 1991, 42:1499-1506.

17. Else MA, Davies WJ, Malone M, Jackson MB: A negative hydraulic message from oxygen-deficient roots of tomato plants? Plant Physiol 1995, 109:1017-1024

18. de Bruxelles GL, Peacock WJ, Dennis ES, Dolferus R: Abscisic acid induces the alcohol dehydrogenase gene in Arabidopsis. Plant Physiol 1996, 111:381-391.

19. He CJ, Morgan PW, Drew MC: Transduction of an ethylene signal is required for cell death and lysis in the root cortex of maize during aerenchyma formation induced by hypoxia. Plant Physiol 1996, 112:463-472.

20. Raskin I, Kende $\mathrm{H}$ : Regulation of growth in stem sections of deepwater rice. Planta 1984, 160:66-72

21. Rijnders JG, Yang YY, Takahashi N, Barendse GW, Blom CW, Voesenek LA: Ethylene enhances gibberelin levels and petiole sensitivity in flooding tolerant Rumex in contrast to intolerant species. Planta 1997, 203:20-23.

22. Visser EJW, Cohen JD, Barendse GWM, Voesenek LACJ: An ethylenemediated increase in sensitivity to auxin induces adventitious root formation in flooded Rumex palustris Sm. Plant Physiol 1996, 112:1687-1692

23. Zhang J, Van Toai T, Huynh L, Preiszner J: Development of floodingtolerant Arabidopsis thaliana by autoregulated cytokinin production. $\mathrm{Mol}$ Breed 2000, 6:135-144.

24. Burrows WJ, Carr DJ: Effects of flooding the root system of sunflower plants on the cytokinin content of the xylem sap. Physiol Plantarum 1969, 22:1105-1112.

25. Xu KN, Xu X, Fukao T, Canlas P, Maghirang-Rodriguez R, Heuer S, Ismail AM, Bailey-Serres J, Ronald PC, Mackill DJ: Sub1A is an ethylene-responsefactor-like gene that confers submergence tolerance to rice. Nature 2006, 442:705-708

26. Ratcliffe RG: In vivo NMR studies of the metabolic responses of plant tissues to anoxia. Ann Bot 1997, 79:39-48.

27. Roberts JKM, Callis J, Wemmer D, Walbot V, Jardetzky O: Mechanism of cytoplasmic $\mathrm{pH}$ regulation in hypoxic maize root tips and its role in survival under hypoxia. Proc Natl Acad Sci 1984, 81:3379-3383.

28. Fox GG, McCallan NR, Ratcliffe RG: Manipulating cytoplasmic pH under anoxia: A critical test of the role of $\mathrm{pH}$ in the switch from aerobic to anaerobic metabolism. Planta 1995, 195:324-330.

29. Snedden WA, Arazi T, Fromm H, Shelp BJ: Calcium/calmodulin regulation of soybean glutamate decarboxylase. Plant Physiol 1995, 108:543-549.

30. Shelp BJ, Bown AW, McLean MD: Metabolism and functions of gammaaminobutyric acid. Trends Plant Sci 1999, 4:446-452.

31. Taylor ER, Nie XZ, MacGregor AW, Hill RD: A cereal haemoglobin gene is expressed in seed and root tissues under anaerobic conditions. Plant Mol Biol 1994, 24:: 853-862

32. Chaparro-Giraldo A, Chabregas SM, Azevedo RA, Silva MC, Barata RM: Soybean leghemoglobin targeted to potato chloroplasts influences growth and development of transgenic plants. Ann Bot 2005, 96:831-844.

33. Wittenberg JB, Wittenberg BA: Mechanisms of cytoplasmic hemoglobin and myoglobin function. Annu Rev Biophys Biophys Chem 1990, 19:217-241.

34. Duff SM, Wittenberg JB, Hill RD: Expression, purification, and properties of recombinant barley (Hordeum sp.) hemoglobin. Optical spectra and reactions with gaseous ligands. J Biol Chem 1997, 272:16746-16752.

35. Mattana M, Coraggio I, Bertani A, Reggiani R: Expression of the enzymes of nitrate reduction during the anaerobic germination of rice. Plant Physiol 1994, 106:1605-1608.

36. Saab IN, Sachs MM: A flooding-induced xyloglucan endotransglycosylase homolog in maize is responsive to ethylene and associated with aerenchyma. Plant Physiol 1996, 112:385-391.
37. Qiu FZ, Zheng YL, Zhang ZL, Xu SZ: Mapping of QTL Associated with Submergence Tolerance during the Seedling Stage in Maize. Ann Bot 2007, 99:1067-1081.

38. Tang $W H$, Zhang ZX, Zou XL, Zheng YL: Functional genomics of maize submergence tolerance and cloning of the related gene Sicyp51. Sci China C Life Sci 2005, 48:337-345.

39. Zhang ZX, Tang WH, Tao YS, Zheng YL: cDNA microarray analysis of early response to submerging stress in Zea mays roots. Russ J Plant Physiol 2005, 52:39-43.

40. Zhang ZX, Zou XL, Tang WH, Zheng YL: Revelation on early response and molecular mechanism of submergence tolerance in maize roots by microarray and suppression subtractive hybridization. Environ Exp Bot 2006, 58:53-63.

41. Agarwal S, Grover A: Isolation and Transcription Profiling of Low-O2 Stress-Associated cDNA Clones from the Flooding-stress-tolerant FR13A Rice Genotype. Ann Bot 2005, 96:831-844.

42. Liu F, Vantoai T, Moy LP, Bock G, Linford LD, Quackenbush J: Global Transcription Profiling Reveals Comprehensive Insights into Hypoxic Response in Arabidopsis. Plant Physiol 2005, 137:1115-1129.

43. van Dongen JT, Frohlich A, Ramirez-Aguilar SJ, Schauer N, Fernie AR, Erban A, Kopka J, Clark J, Langer A, Geigenberger P: Transcript and metabolite profiling of the adaptive response to mild decreases in oxygen concentration in the roots of arabidopsis plants. Ann Bot 2009, 103:269-280

44. Mustroph A, Lee SC, Oosumi T, Zanetti ME, Yang H, Ma K, YaghoubiMasihi A, Fukao T, Bailey-Serres J: Cross-Kingdom Comparison of Transcriptomic Adjustments to Low-Oxygen Stress Highlights Conserved and Plant-Specific Responses. Plant Physiol 2010, 152:1484-1500.

45. Paul AL, Schuerger AC, Popp MP, Richards JT, Manak MS, Ferl RJ: Hypobaric Biology: Arabidopsis Gene Expression at Low Atmospheric Pressure. Plant Physiol 2004, 134:215-223

46. Hirt H: Multiple roles of MAP kinase in plant signal transduction. Trends Plant Sci 1997, 2:11-15.

47. Liu YD, Zhang SQ: Phosphorylation of 1-Aminocyclopropane-1-Carboxylic Acid Synthase by MPK6, a Stress-Responsive Mitogen-Activated Protein Kinase, Induces Ethylene Biosynthesis in Arabidopsis. Plant Cell 2004, 16:3386-3399.

48. Drew MC, Jackson MB, Giffard S: Ethylene-promoted adventitious rooting and development of cortical air spaces (aerenchyma) in roots may be adaptive responses to flooding in Zea mays L. Planta 1979, 147:83-88.

49. Hattori $Y$, Nagai K, Furukawa S, Song XJ, Kawano R, Sakakibara H, Wu J, Matsumoto T, Yoshimura A, Kitano H, Matsuoka M, Mori H, Ashikari M: The ethylene response factors SNORKEL1 and SNORKEL2 allow rice to adapt to deep water. Nature 2009, 460:1026-1030.

50. Hattori Y, Miura K, Asano K, Yamamoto E, Mori H, Kitano H, Matsuoka M, Ashikari M: A Major QTL Confers Rapid Internode Elongation in Response to Water Rise in Deepwater Rice. Breed Sci 2007, 57:305-314.

51. Hattori Y, Nagai K, Mori H, Kitano H, Matsuoka M, Ashikari M: Mapping of three QTL that regulate internode elongation in deepwater rice. Breed Sci 2008, 58:39-46.

52. Fukao T, Bailey-Serres J: Submergence tolerance conferred by Sub1A is mediated by SLR1 and SLRL1 restriction of gibberellin responses in rice. Proc Natl Acad Sci 2008, 105:16814-16819.

53. Nagai K, Hattori $Y$, Ashikari M: Stunt or elongate? Two opposite strategies by which rice adapts to floods. J Plant Res 2010.

54. Taylor ER, Nie XZ, Mac Gregor AW, Hill RD: A cereal haemoglobin gene expressed in seed and root tissue under anaerobic conditions. Plant Mol Biol 1994, 24:853-862

55. Dordas C, Hasinoff BB, Rivoal J, Hill RD: Class-1 hemoglobins, nitrate and NO levels in anoxic maize cell-suspension cultures. Planta 2004, 219:66-72.

56. Dordas C, Hasinoff BB, Igamberdiev AU, Manacrsquoh N, Rivoal J, Hill RD: Expression of a stress-induced hemoglobin affects NO levels produced by alfalfa root cultures under hypoxic stress. Plant J 2003, 35:763-770.

57. Li X, Peng RH, Fan HQ, Xiong AS, Yao QH, Cheng ZM, Li Y: Vitreoscilla hemoglobin overexpression increases submergence tolerance in cabbage. Plant Cell Rep 2005, 23:710-715.

58. Igamberdiev AU, Baron K, Manac'h-Little N, Stoimenova M, Hill RD: The haemoglobin/nitric oxide cycle: involvement in flooding. Stress and effects on hormone signalling. Ann Bot 2005, 96:557-564. 
59. Sowa AW, Duff SM, Guy PA, Hill RD: Altering hemoglobin levels changes energy status in maize cells under hypoxia. Proc Natl Acad Sci 1998, 95:10317-10321.

60. D'Angelo G, Duplan E, Boyer N, Vigne P, Frelin C: Hypoxia up-regulates prolyl hydroxylase activity: a feedback mechanism that limits HIF-1 responses during reoxygenation. J Exp Bot 2003, 278:38183-38187.

61. Epstein AC, Gleadle JM, McNeill LA, Hewitson KS, O'Rourke J, Mole DR, Mukherji M, Metzen E, Wilson MI, Dhanda A, Tian YM, Masson N, Hamilton DL, Jaakkola P, Barstead R, Hodgkin J, Maxwell PH, Pugh CW, Schofield CJ, Ratcliffe PJ: C. elegans EGL-9 and mammalian homologs define a family of dioxygenases that regulate HIF by prolyl hydroxylation. Cell 2001, 107:43-54

62. Ohh M, Park CW, Ivan M, Hoffman MA, Kim TY, Huang LE, Pavletich N, Chau V, Kaelin WG: Ubiquitination of hypoxia-inducible factor requires direct binding to the-domain of the von Hippel-Lindau protein. Nat Cell Biol 2000, 2:423-427.

63. Jaakkola P, Mole DR, Tian YM, Wilson MI, Gielbert J, Gaskell SJ, Kriegsheim A, Hebestreit HF, Mukherii M, Schofield CJ, Maxwell PH, Pugh CW, Ratcliffe PJ: Targeting of HIF-to the von Hippel-Lindau Ubiquitylation Complex by O2-Regulated Prolyl Hydroxylation. Science 2001, 292:468-472.

64. Vlad F, Spano T, Vlad D, Daher FB, Ouelhadj A, Kalaitzis P: Arabidopsis prolyl 4-hydroxylases are differentially expressed in response to hypoxia, anoxia and mechanical wounding. Physiol Plantarum 2007, 130:471-483.

65. Asif MH, Trivedi PK, Misra P, Nath P: Prolyl-4-hydroxylase (AtP4H1) mediates and mimics low oxygen response in Arabidopsis thaliana. Funct Integr Genomics 2009, 9:525-535.

66. Drew MC: Oxygen deficiency and root metabolism: injury and acclimation under hypoxia and anoxia. Annu Rev Plant Physiol Plant Mol Biol 1997, 48:223-250.

67. Lasanthi-Kudahettige R, Magneschi L, Loreti E, Gonzali S, Licausi F, Novi G, Beretta O, Vitulli F, Alpi A, Perata P: Transcript Profiling of the Anoxic Rice Coleoptile. Plant Physiol 2007, 144:218-231.

68. Branco-Price C, Kawaguchi R, Ferreira RB, Bailey-Serres J: Genome-wide analysis of transcript abundance and translation in Arabidopsis seedlings subjected to oxygen deprivation. Ann Bot 2005, 96:647-660.

69. Drew MC, Cobb BG, Johnson JR, Andrews D, Morgan PW, Jordan W, He CJ: Metabolic acclimation of root tips to oxygen deficiency. Ann Bot 1994, 74:281-286.

70. Ricard B, Coueé I, Raymond P, Saglio PH, Saint-Ges V, Pradet A: Plant metabolism under hypoxia and anoxia. Plant Physiol Biochem 1994, 32:1-10.

71. Good AG, Crosby WL: Anaerobic Induction of Alanine Aminotransferase in Barley Root Tissue. Plant Physiol 1989, 90:1305-1309.

72. Muench DG, Good AG: Hypoxically inducible barley alanine aminotransferase: cDNA cloning and expression analysis. Plant Mol Biol 1994 24:417-427.

73. Muench DG, Wu Y, Coughlan SJ, Okita TW: Evidence for a CytoskeletonAssociated Binding Site Involved in Prolamine mRNA Localization to the Protein Bodies in Rice Endosperm Tissue. Plant Physiol 1998, 116:559-569.

74. De Sousa CAF, Sodek L: Alanine metabolism and alanine aminotransferase activity in soybean (Glycine max) during hypoxia of the root system and subsequent return to normoxia. Environ Exp Bot 2003, 50:1-8

75. Loreti E, Poggi A, Novi G, Alpi A, Perata P: A Genome-Wide Analysis of the Effects of Sucrose on Gene Expression in Arabidopsis Seedlings under Anoxia. Plant Physiol 2005, 137:1130-1138.

76. Miyashita Y, Good AG: Contribution of the GABA shunt to hypoxiainduced alanine accumulation in roots of Arabidopsis thaliana. Plant Cell Physiol 2008, 49:92-102.

77. Miflin BJ, Lea PJ: The pathway of nitrogen assimilation in plants. Phytochemistry 1976, 15:873-885.

78. Streeter JG, Thompson JF: Anaerobic accumulation of gammaaminobutyric acid and alanine in radish leaves (Raphanus sativus L.). Plant Physiol 1972, 49:572-578.

79. Bown AW, Shelp BJ: The metabolism and functions of $\gamma$-aminobutyric acid. Plant Physiol 1997, 115:1-5.

80. Quimio CA, Torrizo LB, Setter TL, Ellis M, Grover A, Abrigo EM, Oliva NP, Ella ES, Carpena AL, Ito O, Peacock WJ, Dennis ES, Datta SK: Enhancement of submergence tolerance in transgenic rice overproducing pyruvate decarboxylase. J Plant Physiol 2000, 156:516-521.
81. Rahman M, Grover A, Peacock WJ, Dennis ES, Ellis MH: Effects of manipulation of pyruvate decarboxylase and alcohol dehydrogenase levels on the submaergence tolerance of rice. Aust J Plant Physiol 2001, 28:1231-1241.

82. Ismond KP, Dolferus R, De Pauw M, Dennis ES, Good AG: Enhanced low oxygen survival in Arabidopsis through increased metabolic flux in the fermentative pathway. Plant Physiol 2003, 132:1292-1302.

83. Ellis MH, Millar AA, Llewellyn DJ, Peacock WJ, Dennis ES: Transgenic cotton (Gossypium hirsutum) over-expressing alcohol dehydrogenase shows increased ethanol fermentation but no increase in tolerance to oxygen deficiency. Aust J Plant Physiol 2000, 27:1041-1050.

84. Fu H, Dooner HK: Intraspecific violation of genetic colinearity and its implications in maize. Proc Natl Acad Sci 2002, 99:9573-9578.

85. Song $R$, Messing J: Gene expression of a gene family in maize based on noncollinear haplotypes. Proc Natl Acad Sci 2003, 100:9055-9060.

86. Brunner S, Fengler K, Morgante M, Tingey S, Rafalski A: Evolution of DNA sequence nonhomologies among maize inbreds. Plant Cell 2005, 17:343-360.

doi:10.1186/1471-2229-10-189

Cite this article as: Zou et al:: Identification of transcriptome induced in roots of maize seedlings at the late stage of waterlogging. BMC Plant Biology 2010 10:189.

\section{Submit your next manuscript to BioMed Central and take full advantage of:}

- Convenient online submission

- Thorough peer review

- No space constraints or color figure charges

- Immediate publication on acceptance

- Inclusion in PubMed, CAS, Scopus and Google Scholar

- Research which is freely available for redistribution
C Biomed Central 